\title{
Molecular characterization of Mosaic Virus from the cocoa trees showing mosaic symptoms in Yogyakarta, Indonesia
}

\author{
WIWIT PROBOWATI ${ }^{1, \nu}$, SUSAMTO SOMOWIYARJO $^{2, v \vee}$, SEDYO HARTONO $^{2}$ \\ ${ }^{1}$ Program of Biotechnology, Faculty of Science and Technology, Universitas 'Aisyiyah Yogyakarta. Jl. Siliwangi No. 63, Nogotirto, Gamping, Sleman \\ 55592, Yogyakarta, Indonesia. Tel.: +62-274-4469199, Fax.: +62-274-4469204, `email: wiwitprobo@unisayogya.ac.id \\ ${ }^{2}$ Laboratory of Plant Pathology, Faculty of Agriculture, Universitas Gadjah Mada. Jl. Flora, Bulaksumur, Sleman 55281, Yogyakarta, Indonesia. \\ Tel.: +62-274-563062, "“email: soesamto@ faperta.ugm.ac.id
}

Manuscript received: 2 August 2019. Revision accepted: 24 November 2019.

\begin{abstract}
Abstact. Probowati W, Somowiyarjo S, Hartono S. 2019. Molecular characterization of Mosaic Virus From the cocoa trees showing mosaic symptoms in Yogyakarta, Indonesia. Biodiversitas 20: 3698-3704. Indonesia is the world's second-biggest producer of cacao after Ivory Coast with its cacao plantations spreads over 1,652 million hectares and mostly managed by smallholders. Cacao as a beneficial commodity can provide job opportunities for over 1.64 million people, with its contribution of more than US-\$ 1.6 billion/year to national income. However, pest and disease infections are inevitably common constraints for the cacao cultivators. One current disease is caused by Cacao Swollen Shoot Virus (CSSV). Despite its noticeable symptoms on the cacao trees suffering from the disease, the knowledge on both the virus existence and the prevention steps in dealing with it is lacking. The information on the diversity of mosaic virus will help us to comprehend its epidemiologic development and the needed countermeasures, as well as its evolution. This research is intended to study the mosaic disease virus molecularly, the virus was obtained from DR1 clones from Kalibawang cacao plantation in Kulon Progo, Yogyakarta. The virus morphology was observed using a transmission electron microscope applying quick dipping method. The PCR analysis with conserved region ORF1 primers was conducted to detect the viral existence in the infected trees. The identification of CSSV molecular characters was undertaken using PCR sequencing analysis which was then examined using BioEdit and Mega5 programs to initiate a relationship dendrogram. The result showed that the DR1 cacao tree clones from Kalibawang were infected by mosaic virus with mild visual severity of leaf typical symptom. From the electronic microscope observation, a $\pm 100 \mathrm{~nm}$ rod-shaped viral particle with a diameter of $15.3 \mathrm{~mm}$ was found. On the molecular level, the cause of mosaic symptom has CSSV amplified at conserved regions with size $375 \mathrm{bp}$. The results are the first report confirming that the molecular cause of cacao mosaic disease in Indonesia is CSSV. The molecular characters of CSSV in Yogyakarta are very different from those found abroad.
\end{abstract}

Keywords: Cocoa, Cacao Swollen Shoot Virus (CSSV), PCR, sequencing, molecular characters

\section{INTRODUCTION}

Cocoa (Theobroma cacao L.) is one of the significant commodities that play an important role in Indonesian economy. In 2013 Indonesia had the second-largest cocoa producer after Ivory Coast. About $80 \%$ of Indonesia's cocoa production was exported, while the rest was used as raw material for domestic chocolate industry. Indonesian cocoa market opportunity was quite open for both export and domestic needs, so the potential to use cocoa industry as one of the growing support and income distribution was quite open (Rifin 2013).

The obstacle commonly faced by cacao cultivation in Indonesia is a number of pests and diseases that are mostly caused by viruses; one of which is mosaic disease. Although mosaic disease has been found in some cocoa farms in Indonesia, there has no in-depth study of the molecular characters of the virus that causes mosaic disease. The nature and characters of Cacao Swollen Shoot Virus (CSSV) which was suspected to generate mosaic symptoms in Indonesia have not yet clearly understood, therefore, the further research is needed to prevent the possibility of the virus from creating a new and more malignant mutants, especially for the superior clones that cannot stand of the disease.

The viral disease in cocoa plants was discovered and studied for the first time by Steven in 1936 in Ghana, West Africa. Back at that time, the disease was called "swollen shoot disease of cacao" and still considered as a disease of "die back". The disease was perceived to be caused by a virus called Cacao Swollen Shoot Virus (CSSV). It was a dangerous disease because it can thwart cocoa harvests. In Indonesia, mosaics on cocoa were first reported by Semangun in 1962 who strongly suspected that the disease was caused by a virus. The first fact that reinforced this conjecture was the success of Semangun (1962) in transmitting the disease by means of grafting and vector Pseudococcus sp. and Ferrisia virgate Cock. Although the subsequent researchers had obtained the evidence and were agreed that the disease was caused by a virus, no common opinion identification of the group of the virus was reached. Semangun (1988) suspected that mosaic disease in Indonesia was identical to leaf mottles in West Africa. Kenten and Wood (1976), as well as Parnata (1976), argued that mosaic disease in North Sumatera was caused by one of the strains of CSSV. However, of many 
symptoms caused by CSSV, swollen symptoms found in stem and roots were not yet found. In addition, Triharsa et al. (1977) proved that the size of mosaic virus particle in Java lay between CSSV and CMLV (Cocoa Mottle Leaf Virus). The nature and characters of mosaic disease in Indonesia which is caused by CSSV are not yet clearly understood. Therefore, further identification of the morphology and molecular characters of the virus that causes the mosaic disease on cocoa plants is needed. The popular and widely cultivated clones in Indonesia include DR1, DR2, and DR38 which are planted as clonal plants by attaching them to the rootstock of seedling (seed origin) (Ruruk and Langsa 2007).

The research conducted at the cocoa farms owned by the small growers in Kalibawang, Kulonprogo, Yogyakarta, Indonesia was aimed to identify the morphology of mosaic virus particle using electron microscope, molecular identification of CSSV causing mosaic disease on cocoa plant, and to study the relationship between CSSV isolate in Yogyakarta and other CSSV isolates in the world. The benefits of this research are expected to provide the scientific information on the molecular characters of mosaic virus causing mosaic disease on cocoa plants in Indonesia. The diversity of mosaic virus which is strongly assumed to be induced from CSSV, in turn, will help the understanding of its epidemiological development and how to control it, as well as the evolution of its population. As a result, the resistance to CSSV can be taken into account as one of the factors in selecting new varieties of cocoa plants.

\section{MATERIALS AND METHODS}

\section{Study area}

This research was conducted at cocoa farm in Kalibawang, Kulonprogo District, Yogyakarta Province, Indonesia. The observation on the virus morphology was done at TEM Laboratory of Mathematics and Sciences Faculty of Gadjah Mada University, Yogyakarta. Then the isolation and molecular identification were performed at Plant Molecular Biology Laboratory, Faculty of Agriculture, Shizuoka University, Japan. This study was conducted from September 2012 to March 2013.

\section{Materials}

The material of the study was cocoa clones cultivated by DR (Djati Roenggo). The samples were cacao leaves of 15 plants with mosaic symptoms. The control group used was asymptomatic leaves of healthy cacao plants. The materials used for DNA isolation included the symptomatic cacao leaf samples and healthy leaves, liquid nitrogen, and Nucleon Phytopure kit. The Materials used for CSSV detection included $10 \mu \mathrm{L}$ tip (Eppendorf, Germany), 200 $\mu \mathrm{L}$ tip (Eppendorf, Germany), $1000 \mu \mathrm{L}$ tip (Eppendorf, Germany), $0.2 \mathrm{~mL}$ tube, $1.5 \mathrm{~mL}$ tube, CSSV primer by (Quaninoo et.al., 2008) forward (5 'AAC CTT GAG TAC CTT GAC CT 3') and reverse (5 'TCA TTG ACC AAC CCA CTG GTC AAG 3'), dNTP,10x LA PCR buffer II $(\mathrm{Mg} 2+$ free $), \mathrm{MgCl} 2$, distilled water, and LA Taq. The materials used for electrophoresis of PCR product samples were: agarose (Roth, Germany), TBE 1X, Syber safe (Invitrogen, USA) and 1kb DNA ladder (Invitrogen, USA).

The research instruments included transmission electron microscope (JEM 1400, Japan), UV-VIS spectrophotometer (Beckman, Germany), personal master-cycler (Eppendorf, Germany) and Backman-type coal sequencing machines and a set of data analysis of BioEdit, Genetyx, and Mega5 software.

\section{Research procedure \\ Samples preparation}

Symptomatic and healthy (controlled) cacao leaves were used as samples for DNA isolation. The leaves taken from the field were directly extracted. The leaf samples were also preserved in a freezer with a temperature of $20^{\circ} \mathrm{C}$ or in a fresh dry condition using silica gel as a bending agent. The primer indicates in Table 1.

\section{Virus morphological observation}

The Quick deeping method was used with 400 mesh grid that had been coated with collodion and carbon powder. Next, the prepared samples were dyed into the solution. The virus uptake was previously dissolved in ammonium molybdate 1\% pH 7 then dried (Harris 1997). The prepared virus was attached to the grid and observed under an electron microscope (Jeol JEM 1400, Japan) which was operated at $100 \mathrm{KV}$.

\section{Isolation of DNA with Nucleophile Phytopure kit}

The stages of DNA isolation in this study were in accordance with the protocols of the Nucleophile Phytopure kit.

\section{Quantitative test of isolated DNA}

Before measuring the concentration and purity of DNA, DNA dilution was firstly performed. DNA dilution was performed using 50x dilution factor. The samples were taken as much as $2 \mu \mathrm{L}$ then put into $1.5 \mathrm{~mL}$ tube. The measurement of absorbance was conducted and repeat twice at wavelength $260 \mathrm{~nm}$ and $280 \mathrm{~nm}$.

\section{CSSV gene detection by Polymerase Chain Reaction (PCR)}

The study used on primer type that was estimated to be able to amplify the genes in the conserved ORF1 CSSV region. The next step was to make the solution of reaction for PCR consisting of DNA genome, PCR kit, and specific primer for CSSV genes (Table 2). After the mixture was well-blended, the next stage was the amplification of CSSV genes using PCR. Below are the cycles used (Table 3). The PCR product was visualized using $1 \%$ of agarose gel electrophoresis which was further pictured with UV transilluminator.

Table 1. Oligonucleotide primer with PCR program to detect CSSV

\begin{tabular}{lcc}
\hline Primer sequence & \multicolumn{2}{c}{ Program* Reference } \\
\hline 5'-AACCTTGAGTACCTTGACCT-3' & 1 & $\begin{array}{l}\text { Quainoo et } \\
\text { al. 2008 }\end{array}$ \\
5'-TCATTGACCAACCCACTGGTCAAG-3' & \\
\hline
\end{tabular}


Note: * 1: 30 times $94^{\circ} \mathrm{C}-1$ minutes, $94^{\circ} \mathrm{C}-45$ seconds, $65^{\circ} \mathrm{C}-45$ seconds, $72^{\circ} \mathrm{C}-2$ minutes, $72^{\circ} \mathrm{C}-10$ minutes

Table 2. Mixed Composition reaction LA PCR

\begin{tabular}{ll}
\hline Reagent & Volume \\
\hline Cacao DNA & $1 \mu \mathrm{L}$ \\
Primer & \\
$20 \mu \mathrm{M}$ 5'-Forward & $2 \mu \mathrm{L}$ \\
$20 \mu \mathrm{M}$ 3'-Reverse & $2 \mu \mathrm{L}$ \\
Dntp & $16 \mu \mathrm{L}$ \\
$10 x$ LA PCR buffer II & $10 \mu \mathrm{L}$ \\
$\left(\mathrm{Mg}^{2+}\right.$ free) & $10 \mu \mathrm{L}$ \\
$25 \mathrm{Mm} \mathrm{MgCl}_{2}$ & $1 \mu \mathrm{L}$ \\
LA taq & $58 \mu \mathrm{L}$ \\
Distilled water & $100 \mu \mathrm{L}$ \\
Total &
\end{tabular}

Table 3. Formula of PCR Reaction to detect CSSV (Quainoo, 2010)

\begin{tabular}{lcll}
\hline Reaction & Temperature & Time & \\
\hline Pre-denaturation & $94{ }^{\circ} \mathrm{C}$ & 1 minute & - \\
Denaturation & $94{ }^{\circ} \mathrm{C}$ & 45 seconds & 30 cycles \\
Annealing & $65^{\circ} \mathrm{C}$ & 45 seconds & 30 cycles \\
Elongation & $72{ }^{\circ} \mathrm{C}$ & 2 minutes & \\
Post-denaturation & $\mathbf{7 2}{ }^{\circ} \mathrm{C}$ & 10 minutes & - \\
\hline
\end{tabular}

\section{Sequencing and bioinformatics studies}

Forty microliters of sample PCR products showed positive results. The sequencing process was conducted at the Plant Molecular Biology Laboratory, Faculty of Agriculture, Shizuoka University, Japan. The result of sequencing sample data of CSSV Theobroma cacao in the form of nucleotide sequences was inserted into the BLAST program at NCBI for selectable species with high relationship. Furthermore, the CSSV sequence selected through NCBI was further processed by using bioinformatics software such as BioEdit and compared with CSSV sequence results from other researchers obtained from NCBI. Then, the dendrogram results were seen using the MEGA5 program. Thus, the phylogenetic relationship with CSSV isolates in the world could be observed.

\section{RESULTS AND DISCUSSION}

\section{Survey on cocoa plantation}

The observation of the symptoms was done in an area of $800 \mathrm{~m}^{2}$ where cocoa DR1 clones (Djati Runggo 1 Clones) were cultivated in Kalibawang, Kulonprogo, Yogyakarta Special Province and already aged 27 years. The presence of mosaic symptoms in Kalibawang cocoa garden had previously been studied by Fajarwati and Somowiyarjo (2013). DR1 clones are known to be susceptible to viruses and show clear visual symptoms.

On each tree in the field, the symptoms of cocoa swollen shoot disease were spotted on the leaves with the specific style. However, CSSV symptoms were not seen on the stem and root. The symptoms that showing CSSV attacks were very clearly visible on the leaves with a mosaic that had several kinds of patterns.

Figure 1 shows that the specific patterns of CSSV symptoms on cocoa leaves scattered on the leaf blade. As stated by Posnette (1951), there was a continual shift in the motif of the mosaic from time to time. The results of the observations on the field indicated that the different specific patterns appeared to be suitable when compared to the previous studies.

Figure 1.A demonstrates the patches of white or pale, diffuse (limited unclear) and quite round shaped which were scattered erratically on the leaf blade (pattern A). Figure 1.B demonstrates the patches which looked like "chicken feather" with slightly tangled yet finely loose edges that were separated from each other (pattern D) and another type of pattern that was in accordance with the study of Posnette (1951). Figure 1.C includes the symptoms of CSSV with small leaf patches forming a mosaic. Between the mosaic and the parent bones of the leaves were the particular sectors which were dark green with erratic boundaries. This mosaic picture was found on both sides of the leaf, but was still included in the pattern F.

Cocoa plants can be reproduced in two ways; generative and vegetative propagations. In Kalibawang cocoa plantation area, the farmers used side grafting techniques. Side grafting technique is the plant propagation technique using vegetative method by grafting the top stem with understock to merge and grow integratively.

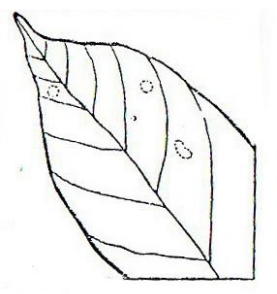

A

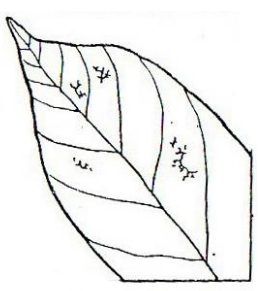

B

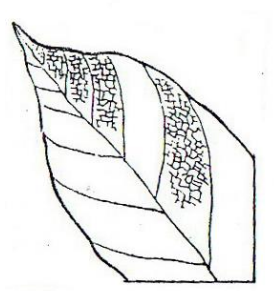

C

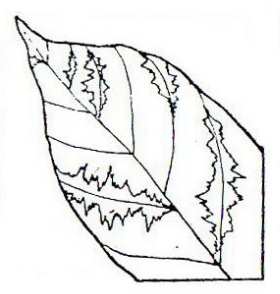

D

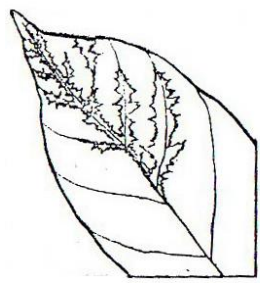

$\mathbf{E}$

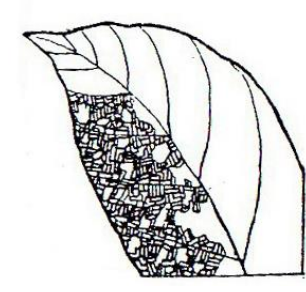

F

Figure 1. Characteristics of CSSV mosaic disease on cocoa leaves (Posnette 1951) 


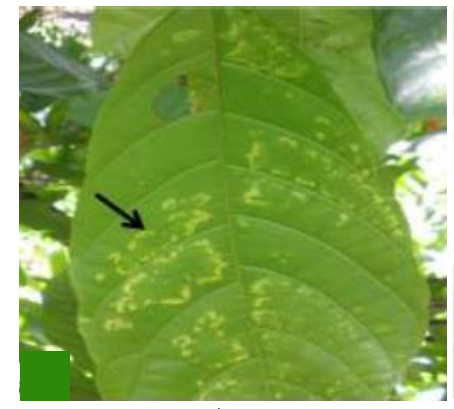

A

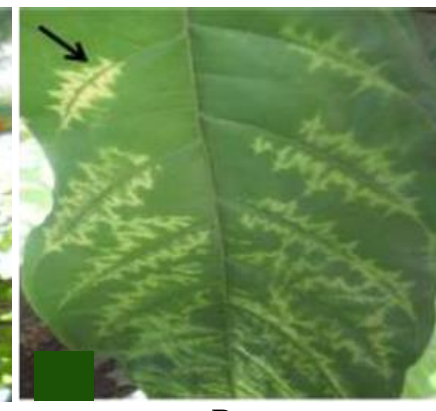

B

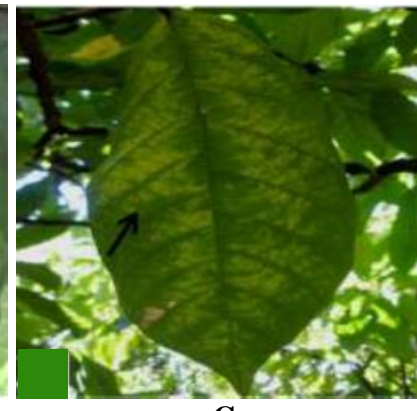

C

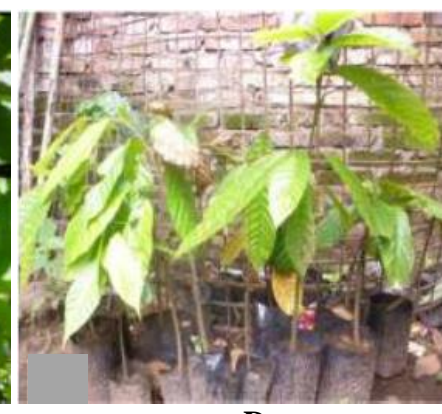

D

Figure 2. Symptoms on the cocoa leaves infected by mosaic-causing viruses in Kalibawang cocoa farms, Kulonprogo District, Yogyakarta Province, Indonesia. Some mosaic features and patterns that appeared on cocoa leaves: A. Pale and slightly rounded spots; B. Patches similar to "chicken feathers"; C. Small patches forming a mosaic; D. Symptoms on 2-year-old cocoa seedlings applying sidegrafting techniques. Black arrows indicate the specific pattern of CSSV.

The results of the survey on the cocoa plant using side grafting techniques which aged 2-years and were ready to acclimatize showed the mosaic symptoms (Figure 2). This incident was very worrying because the provision of cocoa seedlings most of which were sold were already grafted. That could be a means of spreading the virus. In addition, Quainoo et al. (2008) recently found that CSSV could be spread through seeds. Ameyaw et al. (2014) also proved that there was an indication that sowing new seeds from the symptomatic plant seeds would produce symptomatic seedlings as well. Therefore, the free trade of imported cocoa beans from abroad should be closely monitored considering that the spread of the virus could be transmitted through seeds.

\section{Microscopic observation}

Virus morphological observation can be conducted in two methods: quick dipping and ultrathin section. Nonetheless, this study only used quick dipping method for the observation of the virus particles that cause cocoa mosaic. The quick dipping method is the fastest method for preparing the materials used before inserted into an electron microscope. This method uses only a small fraction of the symptomatic leaves that are thinly cut.

The result of the observation using an electron microscope showed rod-shaped virus particles of about 100 nm long (Figure 3.A), while Figure 3.B shows clustering virus particles. The virus particles were suspected to be CSSV particles because they were rod-shaped. The slightly different result was previously encountered in CSSV particles by Brunt and Kenten (1964) which were $121 \mathrm{~nm}$ long in average. The measure was slightly different in this observation because the CSSV characters in this study are different from the similar virus characters in the other countries. This microscopy observation was an early diagnosis to show that the mosaic disease of cocoa plants was caused by CSSV. Nomatter et al. (2017) proved that there is association between cacao swollen shoot with another plant virus disease which creates different virus particles under microscope.

\section{DNA isolation}

DNA isolation was performed for both mosaic symptom and asymptomatic (healthy) cocoa leaves. This stage was performed using a Nucleophile Phytopure kit that was used specifically to isolate plant DNA. The quantitative DNA Test of isolation was performed to measure the quantitative DNA concentration of isolation. The result can be determined by spectrophotometry. The results of the spectrophotometer showed high levels of concentration and purity of DNA with a purity value of more than 1.8 .

\section{Molecular detection of CSSV}

The primer used in this study was a universal primer for CSSV that is the one designed based on the discovery of the conserved regions in the six viral genome isolates published in the National Center for Biotechnology Information (NCBI) databank (AJ608931, AJ609019, AJ609020, AJ781003, CSHCG and AJ534983) Hagen et al. 1993; Muller and Sackey 2005). The primers were CSSV forward 5'-AACCTTGAGTACCTTGACCT-3 'and reverse 5'-TCATTGACCAACCCACTGGTCAAG-3'. The pair of primers is capable to amplify the target area in the conserved region of the ORF1 CSSV genome (Quainoo et al. 2008).

From this optimization, the optimum temperature was obtained to get the best result which was at $65^{\circ} \mathrm{C}$. In electrophoresis, to find the existence of target DNA, $1 \mathrm{~kb}$ ladder DNA marker (Microzone) Ltd is used. From the results, it revealed that the DNA had CSSV gene with a length of $375 \mathrm{bp}$ (Figure 4).

\section{Sequence analysis of CSSV}

The CSSV genome was sized of $7161 \mathrm{bp}$ with genetic material in form of double-stranded DNA (Hagen et al. 1993). The sequencing was directly done from the DNA PCR products of Yogyakarta isolate (originally from Yogyakarta) with forwarding primer and reverse primer. 


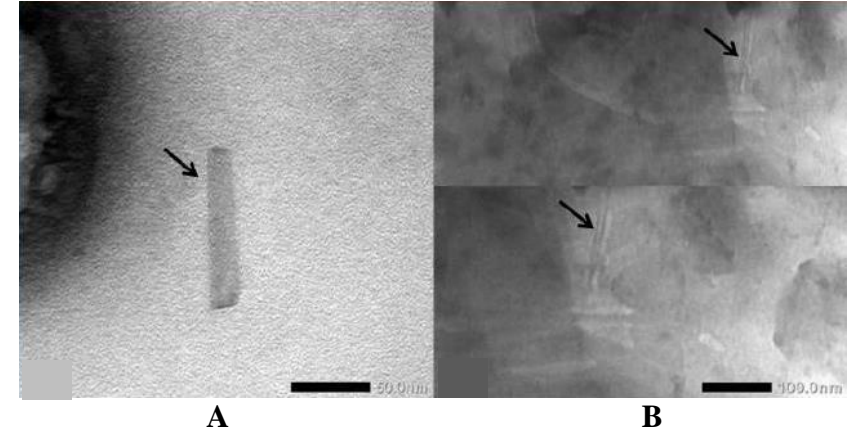

Figure 3. The result of virus morphological observation results using electron microscope by Quick dipping method: A. Virus particles in the form of solitary branch $(B a r=50 \mathrm{~nm})$; B. Virus particles in the form of cluster branches $(B a r=100 \mathrm{~nm})$

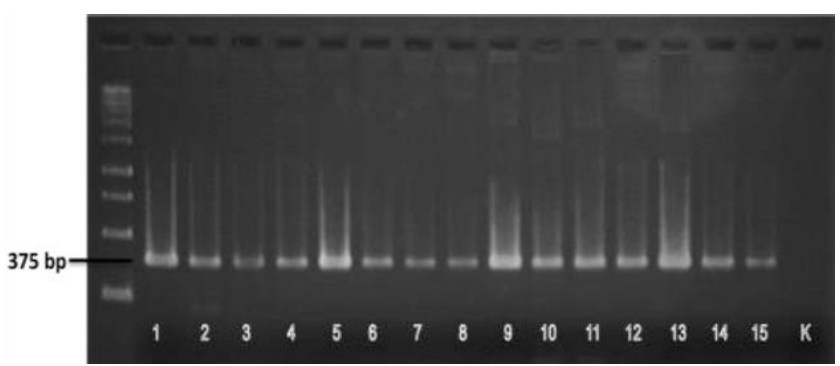

Figure 4. Electrophoresis of PCR analysis of CSSV isolates from some cacao mosaic plants. Gene was detected at 375 bp (number $1-15$ = mosaic symptomatic cocoa plants, $\mathrm{K}=$ healthy cocoa plant)

The result of CSSV DNA sequencing on the sample showed the length of 375 nucleotide sequences (nt) which formed the complete sequence. The analysis employing Basic Local Alignment Search Tool (BLAST) was performed on the nucleotide sequence of Yogyakarta's CSSV isolate samples linked to the NCBI (National Center for Biotechnology Information) database. The BLAST results indicated that all Yogyakarta's isolate samples tended to resemble the nucleotide sequences from CSSV Togo DNA (AJ781003.1), Ivory Coast (L14546.1), Togo (AJ534983.1), Ghana (AJ609020.1), Ghana (AJ609019.1), and Ghana (AJ608931).

The CSSV DNA sequence analysis showed that the sequences were part of ORF1. ORF1 encodes hypothetical proteins and has a conserved region that is often used for early detection of CSSV identification (Quainoo et al. 2008). Multiple alignment sequences were performed to match the sequences, investigate the comparison between the sample sequences (Yogyakarta isolates) and the other sequences related to their positions. From the multiple alignment sequences, 190 nucleotide bases and 63 CSSV amino acids were obtained. Based on the BLAST analysis, the corrected sequence of CSSV corresponded to the part of ORF1 sequence from the complete sequences of a number of fully identified CSSV isolates in NCBI. It proved that PCR sequences of DNA were the amplification targets of the conserved area primers for CSSV.

The sequence analysis results showed that there were a number of different nucleotide bases at certain positions in the CSSV DNA sequence. After the CSSV DNA sequence of Yogyakarta, isolates was compared with the sequences of isolates from other countries, 48 positions of the CSSV DNA sequence showing the nucleotide base differences (Figure 5) were found. These differences indicated the occurrence of point mutations in form of nucleotide base substitution in Yogyakarta isolates. Nucleotide base substitution that occurred was transitional and transverse.

The transitional substitution occurs if a purine base transforms into another purine base as well as a pyrimidine base. In Figure 5 the transition of the bases $\mathrm{T} \rightarrow \mathrm{C}, \mathrm{A} \rightarrow \mathrm{G}$ took place. While transverse substitution point mutations occurred with the base A $\rightarrow$ T, and T $\rightarrow$ A. Subtransit base substitution of purine nucleotide base changes into pyrimidine base and vice versa. Substitution in a $63^{\text {rd }}$ and $68^{\text {th }}$ base caused changes in the formed amino acid.

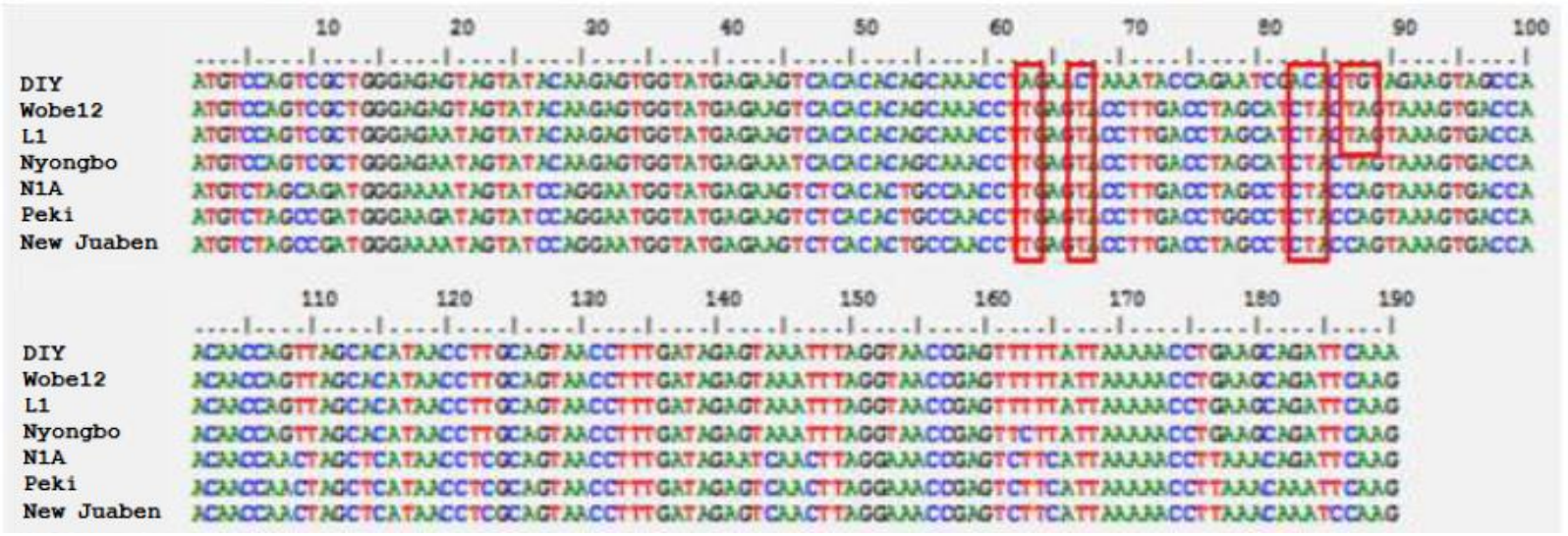

Figure 5. Homology of nucleotide sequences from some of ORF1 on one isolate of CSSV Yogyakarta and some isolates from abroad using multiple sequence alignment analysis with BioEdit program. Wobe12 (AJ781003.1) = Togo; L1 (L14546.1) = Ivory Coast; Nyongbo $($ AJ534983.1) $=$ Togo; N1A $($ AJ609020.1 $)=$ Ghana; Peki $($ AJ609019.1 $)=$ Ghana; New Juaben $($ AJ608931.1 $)=$ Ghana. Red box: nucleotide substitution 


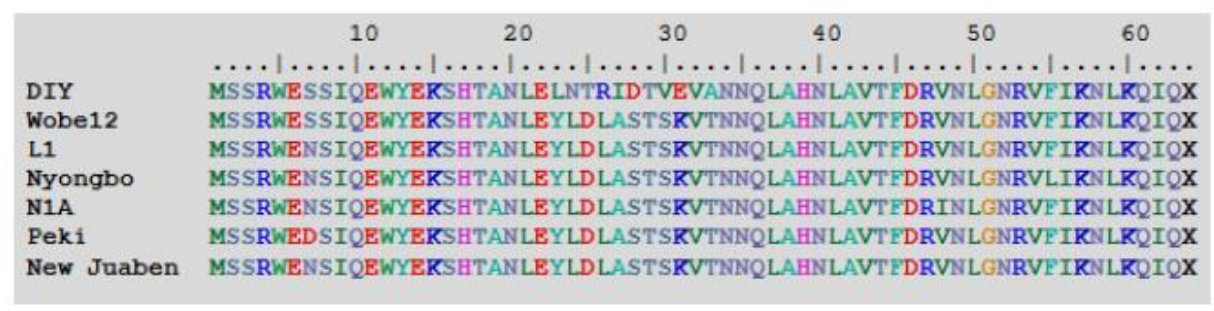

Figure 6. Homology of amino acids ORF1 in CSSV Yogyakarta isolates some isolates from abroad using multiple sequence alignment analysis with BioEdit program. Wobe12 $($ AJ781003.1) = Togo; L1 (L14546.1) = Ivory Coast; Nyongbo $($ AJ534983.1) = Togo; N1A $($ AJ609020.1 $)=$ Ghana; Peki $($ AJ609019.1 $)=$ Ghana; New Juaben $($ AJ608931.1 $)=$ Ghana

Table 4. Percentages of similarity of nucleotide and amino acid-base of some ORF1s between Yogyakarta CSSV isolates and some isolates from abroad analyzed using BioEdit software

\begin{tabular}{|c|c|c|c|c|c|c|c|}
\hline & DIY & Wobe 12 & L1 & Nyongbo & N1A & Peki & New Juaben \\
\hline DIY & ID & & & & & & \\
\hline Wobe 12 & $87.3(85.7)$ & ID & & & & & \\
\hline $\mathrm{L} 1$ & $86.8(84.1)$ & $99.4(98.4)$ & ID & & & & \\
\hline Nyongbo & $85.7(82.5)$ & $98.4(96.8)$ & $98.9(98.4)$ & ID & & & \\
\hline N1A & $74.7(82.5)$ & $86.3(96.8)$ & $86.8(98.4)$ & $85.7(96.8)$ & ID & & \\
\hline Peki & $74.2(84.1)$ & 85.7 (98.4) & 86.3 (98.4) & $85.2(96.8)$ & $97.3(96.8$ & ID & \\
\hline New Juaben & $74.7(84.1)$ & $86.3(98.4)$ & $86.3(100)$ & $85.7(98.4)$ & $97.8(98.4)$ & $98.4(98.4)$ & ID \\
\hline
\end{tabular}

Note: The isolates with the bold print are the results of sequence analysis in this study; The data in parentheses are the percentages of amino acid similarity; Wobe12 (AJ781003.1) = Togo; L1 $($ L14546.1) = Ivory Coast; Nyongbo $($ AJ534983.1) = Togo; N1A $($ AJ609020.1 $)=$ Ghana; Peki $($ AJ609019.1 $)=$ Ghana; New Juaben $($ AJ608931.1 $)=$ Ghana
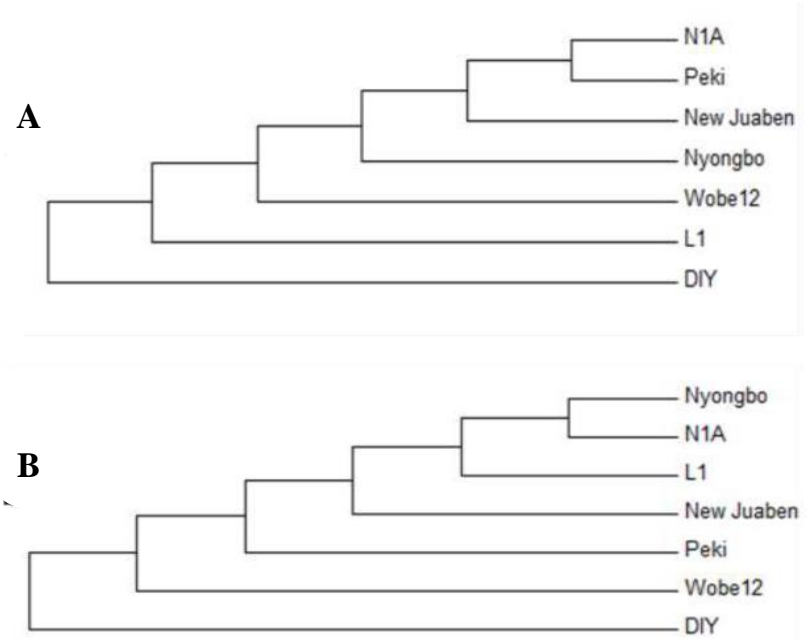

Figure 7. Dendogram of molecular relationship of CSSV isolate of ORF1 nucleotide Yogyakarta and some isolates from abroad using Mega5 Construct Neighbor-Joining Tree program a) Based on the difference of nucleotide sequence in ORF1; b) Based on the amino acid variation of ORF1; L1 (L14546.1) = Ivory Coast; Nyongbo (AJ534983.1) = Togo; Wobe12 (AJ781003.1) $=$ Togo; N1A $($ AJ609020.1 $)$ = Ghana; Peki $($ AJ609019.1 $)=$ Ghana; New Juaben $($ AJ608931.1) $=$ Ghana.

The relationship of the test sample with other isolates was analyzed using the Mega5 program in form of a phylogenetic tree dendrogram. After being compared with some isolate nucleotide sequences from abroad,
Yogyakarta isolates were revealed to have long distant relation to CSSV isolates from abroad (Figure 7). The phylogenetic tree (relationship) analysis on Yogyakarta isolate test sample and some isolates existing in the database based on ORF1 nucleotide sequence yielded several groups. The isolates of N1A (Ghana) and Peki (Ghana) had the closest relationship followed by the isolates of New Juaben (Ghana), Nyongbo (Togo), Wobe12 (Togo), L1 (Cote d'Ivoire) and the most distant relationship of Yogyakarta isolates. The patterns of relationship showed that the grouping was not based on the continent of origin that was between African and Asian groups, but more on the distance of evolution between the isolates in some countries.

The molecular diversity of CSSV isolates is indicated by the presence of nucleotide base variations in the sequencing of DNA and amino acids formed. Each isolate has a specific type of amino acid that distinguishes one isolate to another. Both of them are important to homology analysis because according to Muller et al. (2018), the presence of nucleotide base variations in the sequencing of DNA produce different dendrogram compared homology analysis of amino acid. Amino acid sequence derived from translation of nucleotide base in codon triplet.

The result of homology analysis showed that CSSV Yogyakarta isolates had the highest percentage of similarity in nucleotide base and amino acid with CSSV of Wobe 12 isolate, namely $87.3 \%$ and $85.7 \%$ respectively (Table 4). Furthermore, Yogyakarta isolates had decreasing percentage in homological similarity with L1, Nyongbo, N1A, Peki, and New Juaben. 
The percentage of amino acid similarity with identified CSSV which is $<70 \%$ indicated that the isolate is a different species (Van Regenmortel et al. 2000). When CSSV Yogyakarta isolates were compared with CSSV isolates from abroad, the percentage of nucleotide base and amino acid similarity ranged between $74.2 \%-87.3 \%$ and between $82.5 \%$ - $85.7 \%$ respectively. This revealed that CSSV Yogyakarta isolates were still the same species with those overseas called Wobe12 isolate from Togo namely at $87.3 \%$ (nt) and $85.7 \%$ (aa) respectively species that had been published. Walker et al., 2019 proved that the percentage of amino acid similarity which is under $70 \%$ will change to virus taxonomy according to the International Code of Virus Classification and Nomenclature ratified by the International Committee on Taxonomy of Virus (ICTV) 2019.

This molecular research suggests that this is the first report to prove that the mosaic-causing virus found in Kalibawang cocoa plantation in Yogyakarta is CSSV. In the case that the cocoa plantation in Indonesia is attacked by the same mosaic symptom it can be indicated that the cocoa clones are attacked by CSSV. It will result in a serious implication on the preparation of healthy (virusfree) cocoa seeds. We must also pay more attention to the entres part used in side-grafting technique. The preliminary screening employing PCR technique can also be done on the plants which will be used as cocoa seedlings. In addition, the recent evidence showing that CSSV can also be transmitted through seeds (Quainoo et al. 2008) should make us more alert to the imported cocoa beans for the purpose of preparing superior clones of cocoa.

\section{REFERENCES}

Ameyaw, G.A, Dzahini-Obiatey HK, Domfeh O. 2014. Perspectives on cocoa swollen shoot virus disease (CSSVD) management in Ghana. Crop Protect 65: 64-70.

Brunt AA, Kenten RH, Nixon HL. 1964. Some properties of cocoa swollen shoot virus. J Gen Microbiol 36: 303-309.
Fajarwati D, Somowiyarjo S. 2013. Penularan Penyakit Mosaik Pada Tanaman Kakao. [Dissertation]. Universitas Gadjah Mada, Yogyakarta. [Indonesian]

Hagen LS, Jacquemond M, Lepingle A, Lot H, Tepfer M. 1993. Nucleotide sequence and genomic organization of cacao swollen shoot virus. Virology 196: 619-628.

Harris JR. 1997. Negative Staining and Cryoelectron Microscopy: thinfilm techniques. RMS Microscopy Handbook Number 35, BIOS Scientific Publishers Ltd., Oxford.

Kenten RH, Woods RD. 1976. A virus of the cocoa swollen shoot group infecting cocoa in North Sumatra. PANS 22 (4): 488-490.

Muller E, Ravel S, Agret C, Abrokwah F, Dzahini-Obiatey H, Galyuon I, et al. 2018. Next generation sequencing elucidates cacao badnavirus diversity and reveals the existence of more than ten viral species. Virus Res 244: 235-251.

Muller E, Sackey S. 2005. Molecular variability analysis of five new complete cacao swollen shoot virus genomic sequences. Arch Virol 150: 53-66.

Nomatter C, Kouakou K, Aka R, Ameyaw G, Gutierrez OA, Herrmann HW. 2017. The proposed new species, cacao red vein virus, and three previously recognized badnavirus species are associated with cacao swollen shoot disease. Virol J 14: 199-213.

Parnata Y. 1976. Beberapa catatan mengenai penyakit virus tanaman coklat di Sumatra Utara. Bull BPP Medan 7 (1): 5-13. [Indonesian]

Posnette AF. 1951. Virus research at the West African Cacao Research Institute, Tafo, Gold Coast. Trop Agriculture Trin 14 (3): 84.

Quainoo AK, Wetten AC, Allainguillaume J. 2008. Transmission of cocoa swollen shoot virus by seeds. J Virol Methods 150: 45-49.

Rifin A. 2013. Competitiveness of Indonesia's Cocoa Beans Export in the World Market. Intl J Trade Econ Finance 4 (5): 279-281.

Ruruk B, Langsa Y. 2007. Klon unggul kakao nasional. Badan penelitian dan pengembangan pertanian, Balai Pengkajian Teknologi Pertanian (BPTP) Sulawesi Tengah, Sigi. [Indonesian]

Semangun H. 1962. Gedjala-gedjala mozaik pada daun tjoklat. Univ. Gadjah Mada Publ. No. 2. Yogyakarta. [Indonesian]

Semangun H. 1988. Penyakit-penyakit tanaman perkebunan di Indonesia. Gadjah Mada University Press, Yogyakarta. [Indonesian]

Steven WF. 1936. Swollen shoot and die-back- a new disease of cocoa. Gold Coast Farrmer 5: 122-144.

Triharsa YB, Sumardiyono, Jumanto. 1977. Penelitian penyakit mosaik pada coklat. Laporan penelitian 1976/1977. Departemen Pertanian RI, Jakarta.

Van Regenmortel MH, Fauquet CM, Bishop DHL, Carsten EB, Estes MK, Lemon SM, Maniloff J, Mayo MA, Pringle DJ, Wickner CR. 2000. Virus Taxonomy. Classification and Nomenclature of Viruses. Academic Press, New York.

Walker P.J, Stuart G. Siddell, Elliot J. Lefkowitz, Acrady R M, Bas E Dutilh et al. 2019. Changes to virus taxonomy and international code of virus classification and nomenclature ratified by the International Committee on Taxonomy of Viruses. Arch Virol 164 (9): 2417-2429. 